INTERNATIONAL HIGHER EDUCATION, Number 73 Fall 2013

Pages 20-21

\title{
Challenges to Top-Ranked Private Universities in Poland JOANNA MUSIAL-SADILEK
}

Joanna Musial-Sadilek recently completed her dissertation on Polish private higher education at the University at Albany. E-mail: jmusial9@gmail.com.

IHE publishes occasional articles from PROPHE, the Program for Research on Private Higher Education, headquartered at the University at Albany. See http://www.albany.edu/.

After years of dramatic increase in demand, Polish higher education enrollment will decline sharply between now and 2025. As Marek Kwiek shows, publicpolicy alternatives will influence the scope of the decline in the public and private sectors (fall 2012 IHE issue). Demographics present a threat to Polish enrollment in general and to the private sector in particular-one of the largest in Europe $(518,200$ students, a 29\% share of Poland's total) in 2011. The private sector has already declined by 18 percent in absolute enrollment and 4 percent in enrollment share in just the last two years. However, the question arises: will leading private higher education institutions be able to face the demographic challenge in ways that spare them from the fate of the private sector generally? The first years of the demographic decline have not ravaged the leading private institutions. The 20 top-ranked private higher education institutions show a 
decline of only 8 percent in raw enrollment and an increase of 3 percent in their share of Poland's total enrollment.

\section{The Demographic Challenges to the Private Sector}

The public sector is preferred over the private in Poland, as in almost all of Europe. It has high status and legitimacy and provides quality education without tuition for full-time students. In contrast, the majority of private higher education institutions have comparatively low status and legitimacy and provide lowquality education, while charging substantial tuition. Hit by reduced demand, public institutions may ease selection requirements and increasingly accept students who in the past would settle for private institutions.

However, the demographic challenge is not uniform throughout the private sector. Poland provides a good case within which to consider subsectoral differences. Its private sector subsumes large differentiation, prominently with a small minority of "semielite" private institutions. That minority of top-ranked ones, however, holds a not insignificant share of private enrollment: the topranked 20 of Poland's 330 private higher education institutions had 20 percent of the private enrollment in 2009 (the top 10 holding 10\% of the enrollment).

Even these top-ranked institutions share several characteristics of the general private sector that leave them vulnerable to the demographic changes. First, their limited research restricts their academic legitimacy and status, making them less attractive to candidates who can enter the public sector. Second, and more starkly, full-time students pay significant tuition at all private higher education institutions, whereas public sector counterparts do not pay tuition. As the number of prospective students decreases, it becomes easier to enter public 
institutions-most of which must fill seats with some students they would previously have rejected. A natural question arises: why should students pay for private higher education institutions if they can attend free public programs? Meanwhile, even the top-ranked private institutions simply do not have substantial nontuition income, which limits their financial ability to build attractive offerings.

\section{Top-Ranked Private Institutions And the Challenge}

Top-ranked private institutions are more vulnerable than public universities to the demographic challenge, for they are in many respects like other private institutions. However, they are simultaneously different from the majority of private institutions in ways to shield them in part from demographic challenge. The huge majority of Poland's private institutions arose after all as "demand absorbers," growing quickly and easily as the 1989 fall of Communism unleashed huge demand and broke the public monopoly. Logically, such institutions are in great trouble when demand itself plummets. In contrast, topranked private institutions strive to be institutions of choice and provide more to their customers than just a place in the higher education system.

Polish top-ranked private institutions tend to have the semielite characteristics of high student status and high quality of faculty members, compared to average ones. Many of their students come from families able to pay the subsector's high tuition. They are willing to pay because the institutions benefit is enough to make it worthwhile, even as the students have increasing options elsewhere. 
An essential serious part is the faculty. These institutions employ wellknown and respected professors. Concentrated in large cities-academic and economic centers-these institutions facilitated the attraction of these professors and the ability to pay competitive salaries. Similarly, these institutions can attract, as part-timers, experts in professional fields that the universities' teaching emphasizes.

There is a reasonable sense that many public university faculty devote themselves primarily to their research. In contrast, top-ranked privates concentrate on teaching much more than research, and administrators expect their faculty to devote themselves to serious teaching efforts. Nonetheless, the top-ranked privates do more research than average private institutions do, which brings knowledge and status to students. Thus, again the top-ranked privates attain a level of academic legitimacy not possible for the demand-absorbing private institutions. Differentiated from average private institutions, the topranked ones manage to compete with good public higher education institutions.

The top-ranked privates do not compete with publics across the board. Just as they do not excel in research, they cannot usually prevail in many expensive fields of study. Yet, private institutions instead concentrate (more than publics do or wish to) on "in demand fields." With their combination of faculty quality and administrative acumen joined with business ties, they can indeed compete in fields such as business administration, law, and psychology.

The agility of the top-ranked private institutions is their international orientation, which may help, in two ways, to expand the possible pool of prospective students. First, by building an international image-through international partnerships, exchange programs, and summer programs- 
institutions attract students from foreign countries, mostly to the east of Poland. Second, by this internationalism, top-ranked private higher education institutions try to attract domestic students who value internationalism and seek opportunities to experience diversity or expand their skills through language opportunities. Of course, internationalism has a good chance only if the quality and status of the institution are judged high enough by students.

\section{CONCLUSiON}

Demographic change will unavoidably shape the higher education system in Poland. As noted in other countries, the private sector will be more affected than the preferred (public) sector; but not all private institutions need to be affected to nearly the same degree. A small number of top-ranked private institutions enjoy semielite characteristics that may shield them, not fully but partly, from the negative impact of the demographic decline. 